\title{
Rational use and cost variation analysis of antitussive-expectorants available in the Indian market: a pharmacoeconomic study
}

\author{
Pramod Kumar Manjhi, Sunil Kumar Singh, Chakrapani Kumar*, Akhilesh Kumar Rana
}

Department of Pharmacology, All India Institute of Medical Sciences (AIIMS), Patna, Bihar, India

\author{
Received: 27 October 2021 \\ Revised: 10 November 2021 \\ Accepted: 11 November 2021 \\ *Correspondence: \\ Dr. Chakrapani Kumar, \\ Email: Drcpkumar10@gmail.com
}

Copyright: () the author(s), publisher and licensee Medip Academy. This is an open-access article distributed under the terms of the Creative Commons Attribution Non-Commercial License, which permits unrestricted non-commercial use, distribution, and reproduction in any medium, provided the original work is properly cited.

\begin{abstract}
Background: Antitussive-expectorants are among the most frequently prescribed drugs by physicians in clinical practice. Upper respiratory tract infections, such as common cold, acute pharyngitis and acute trachea-bronchitis, are the most common of all communicable diseases and significantly increase OPD burden. This study aimed to assess the rational use, cost ratio, and percentage cost variations in different brands of the commonly prescribed antitussiveexpectorants available in the Indian market.

Methods: The cost of antitussive-expectorant manufactured by different pharmaceutical companies was obtained by using drug today Jan-April $2021 \mathrm{vol} 2$. The maximum and minimum price was noted down, cost ratio and percentage cost variation of the individual formulation were analysed.

Results: Analysis of cost ratio and percentage cost variation for each formulation of the antitussive-expectorants drug, syrup $(100 \mathrm{ml})$ chlorpheniramine $(2 \mathrm{mg})$, dextromethorphan $(10 \mathrm{mg})$, phenylephrine $(5 \mathrm{mg})$ combinations show the highest cost ratio and percentage cost variation as 5.30 and 430.25 respectively, and syrup (100 ml) dextromethorphan $(10 \mathrm{mg})$, guaifenesin $(100 \mathrm{mg})$, phenylephrine $(25 \mathrm{mg})$, chlorpheniramine $(4 \mathrm{mg})$ combinations show lowest cost ratio and percentage cost variation as 1.17 and 17.69 respectively.

Conclusions: There was a wide variation in the cost of different brands of antitussive-expectorant drugs available in the Indian market. So, clinicians should be aware of rational use and variations in cost to reduce the treatment cost and increase patient compliance.
\end{abstract}

Keywords: Pharmacoeconomics, Cost ratio, Cost variation, Antitussive-expectorants

\section{INTRODUCTION}

The world health organization (WHO) has defined rational use of drugs as "Patients receive medications appropriate to their clinical needs, in doses that meet their own individual requirements, for an adequate period of time, and at the lowest cost to them and their community."1 This is also stated as the $5 \mathrm{Rs}$, i.e., the right drug at the right dose by the right route at the right time for the right patient. The efficacy, quality, and safety of drugs should be available and affordable for the individual and the community. If the utilization of drugs is not as per the right conditions, it is said as irrational or inappropriate. ${ }^{2}$ The most common types of irrational use of medicines are failure to diagnose, prescribe and dispense as per direction or use different classes of medicine, unnecessary use of antibiotics, overuse of supplementary nutrition, selfmedication, uses of low efficacy and low safety profile drugs lead to morbidity, mortality, poor control and prevention of disease or even minor health problem, antimicrobial resistance and unethical loss of money. Strict clinical instructions for rational use of medicines should be employed for every level of healthcare, proper guidelines for healthcare professionals based on the present clinical scenario. ${ }^{3}$ Upper respiratory tract infections, such as common cold, acute pharyngitis and acute tracheabronchitis, are the most common of all communicable 
diseases and significantly increase OPD burden. Cough is a protective reflex, its purpose being expulsion of respiratory secretion and foreign particles from air passage. It occurs due to stimulation of mechano or chemoreceptors in the throat and respiratory passages or stretch receptors in the lung. Cough may be useful or useless. Useless (non-productive) cough should be suppressed by using an antitussive agent. Useful (productive) cough serves to drain the airway; its suppression is not desirable; may even harmful, except when the amount of expectoration achieved is small compared to the effort of continuous coughing. ${ }^{4}$

Normal healthy children usually cough on an average of 11 per day. ${ }^{5}$ Classification of cough depends on its severity, duration and characteristic. ${ }^{6}$ The acute cough usually lasts less than 4 weeks while chronic cough lasts more than four weeks. ${ }^{7}$ A productive cough is wet and secretary in nature while a dry cough is irritative. ${ }^{8,9}$ Post viral acute cough usually infect the upper respiratory tract and it is the most common respiratory symptom worldwide. ${ }^{10} 50 \%$ of new patients attending primary health centres related to acute cough and is the major source of medical consultation. ${ }^{11}$ An acute cough is more common in children about 4 times than adults and females are more commonly affected than males. ${ }^{12}$ According to epidemiological data, acute cough in a normal individual has an average 14 days duration. ${ }^{13}$ Acute cough in children can resolve in 10 days by $50 \%$ and in 25 days by $90 \% .{ }^{14}$ Prolonged cough can affect social, physical, mental well-being and quality of life. ${ }^{15}$ Acute cough management represents a major challenge in our day to day medical practice. The treatment of cough is the treatment of the cause including avoidance of precipitating factors e.g., smoking. If the cause of cough could not be found then treatment is symptomatic. The drugs used for cough provide symptomatic relief, though the majority of them are of no use/benefit except the centrally acting antitussives which are useful to suppress the useless, unproductive, troublesome cough. Most of the opioid analgesics produce antitussive action in non-analgesic doses i.e., doses below that produce an analgesic effect and they are the most effective cough suppressants; this leads to significant side effects and can be fatal sometimes. ${ }^{16,17}$ Pharyngeal demulcents soothe the throat and reduce afferent impulses from the inflamed/irritated pharyngeal mucosa, thus providing symptomatic relief in dry cough arising from the throat. Expectorants (mucokinetics) are drugs believed to increase bronchial secretion or reduce its viscosity, facilitating its removal by coughing. Sodium and potassium citrate is considered to extend bronchial secretion by salt-action. Potassium iodide is secreted by bronchial glands and may irritate the airway mucosa. Ammonium salts are nauseating-reflexly increase respiratory secretions. A variety of expectorant formulations combined with antitussive/antihistaminic are marked and briskly promoted, but objective evidence of the efficacy of expectorants is non-conclusive. The USFDA has stopped the marketing of all expectorants, except guaifenesin. ${ }^{4}$
Patients from the low socioeconomic group have the rightto-right drug at the right price. The costly drug can increase the financial burden leads to decrease compliance or even non-compliance. There was a gross variation in price of different brands of the same composition present in Indian market. Expensive drugs increase patient treatment costs end up with decreased belief in prescription and increase use of self-medication which can be fatal sometimes. ${ }^{18}$ Hence, this study was conducted to evaluate rational use and cost variation analysis among different brands of antitussive-expectorants available in Indian market.

\section{METHODS}

This study was an analytical type study conducted in the department of pharmacology, all India institute of medical sciences, Patna (Bihar), India after approval from the Institutional Ethics committee. The data for the study of antitussive-expectorants manufactured by different pharmaceutical companies in India, in the different strengths were collected by using drug today (JanuaryApril 2021, vol II) as they are readily available to the source of drug information and are updated regularly. The cost of 10 tablets, syrup in one bottle $(60 \mathrm{ml}$ and $100 \mathrm{ml})$ were calculated. The cost of drugs was also cross-checked at the pharmacy or retail drug store. The difference in the maximum and minimum price of same drug formulation manufactured by different pharmaceutical companies and percentage variations in prices were calculated. The cost ratio, calculated as the ratio of the costlier brand to that of cheapest brand of the same drug, is calculated as follows;

Cost ratio $=$ Price of the costlier brand / Price of the cheapest brand.

The percentage cost variation of each drug should be calculated as follows,

Percentage cost variation $=[($ Maximum cost - minimum cost)/ minimum cost] $\times 100$.

\section{Inclusion criteria}

Drugs belonging to group of antitussive-expectorants only was included. Dosage forms of antitussive-expectorants being a tablet, the syrup, drugs belong to branded manufacturing companies and drugs of same and different strength were also included.

\section{Exclusion criteria}

Antitussive-expectorants drugs in combinations with another group of drugs and drugs with no price information were excluded.

\section{Statistical analysis}

The data obtained from mentioned sources were analyzed using Microsoft excel® 2019 software. The price variations have been expressed in percentages and the results have been shown in tables, bar and a pie chart. 


\section{RESULTS}

The costs of a total of 26 antitussive-expectorant of different formulations available in 238 brands were analysed and a substantial variation in cost was observed. Out of 26 drug formulations studied, 16 (61.53\%) belongs to antitussive, $7(26.92 \%)$ belongs to expectorant and 3 $(11.53 \%)$ belongs to both antitussive-expectorant formulation. Percentage cost variation of 13 drug formulations was more than $100 \%$ out of which 3 drug formulations had more than $200 \%$. The cost ratio was also observed to be very high, and 13 drug formulations had this ratio of more than 2 . Syrup $(100 \mathrm{ml})$ chlorpheniramine (2 mg), dextromethorphan (10 mg), phenylephrine $(5 \mathrm{mg})$ combinations show highest cost ratio and percentage cost variation as 5.30 and 430.25 respectively, and syrup (100 $\mathrm{ml})$ dextromethorphan $(10 \mathrm{mg})$, guaifenesin $(100 \mathrm{mg})$, phenylephrine (25 mg), chlorpheniramine $(4 \mathrm{mg})$ combinations shows lowest cost ratio and percentage cost variation as 1.17 and 17.69 respectively. Syrup $(60 \mathrm{ml})$ phenylephrine $(5 \mathrm{mg})$, chlorpheniramine $(2 \mathrm{mg})$, paracetamol $(250 \mathrm{mg})$ combination shows highest cost ratio and percentage cost variation as 2.22 and 122.22 respectively, and syrup $(60 \mathrm{ml})$ dextromethotphan $(7.5$ $\mathrm{mg})$, pseudoephdrine $(15 \mathrm{mg}$ ) combination shows lowest cost ratio and percentage cost variation as 1.186 and 18.64 respectively. Tab dextromethorphan $(10 \mathrm{mg})$ shows the highest cost ratio and percentage cost variation as 1.96 and 96.55 respectively, and tab dextromethorphan $(20 \mathrm{mg})$ shows the lowest cost ratio and percentage cost variation as 1.60 and 60.00 respectively. Clinicians preferred those drugs that possessed a cost ratio of less than 2 and percentage cost variation less than 100 . More than $88 \%$ of the preparations were fixed-dose combinations (FDCs). The majority of the cough and cold preparations had 3-4 constituents. Many preparations contained more than one constituent of the same pharmacological group. Some preparations had constituents with opposing action. A wide variation in the amount of each constituent present per dose in different formulations was observed. Rationality assessment of the FDC preparations revealed that most of the preparations were irrational and had no documented benefit in the treatment of the common cold. Availability of such a large number of irrational FDCs for cough and cold requires a serious review of the legal provisions in India for drug manufacturing and marketing.

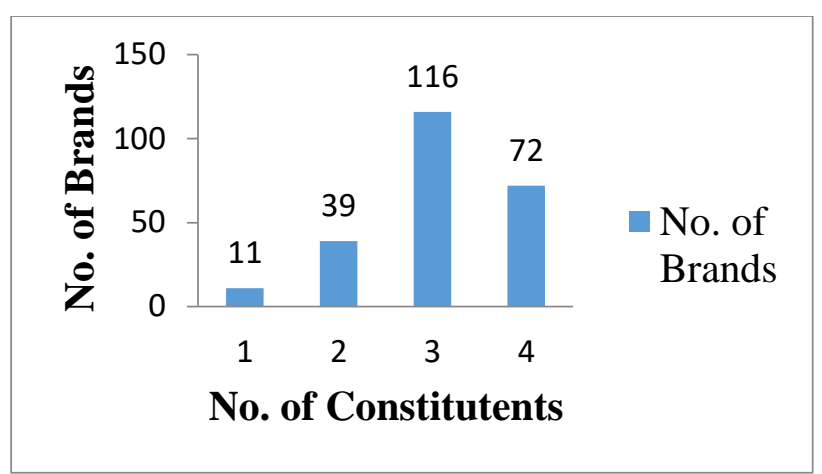

Figure 1: Number of constituents and brand by pharmaceutical companies.

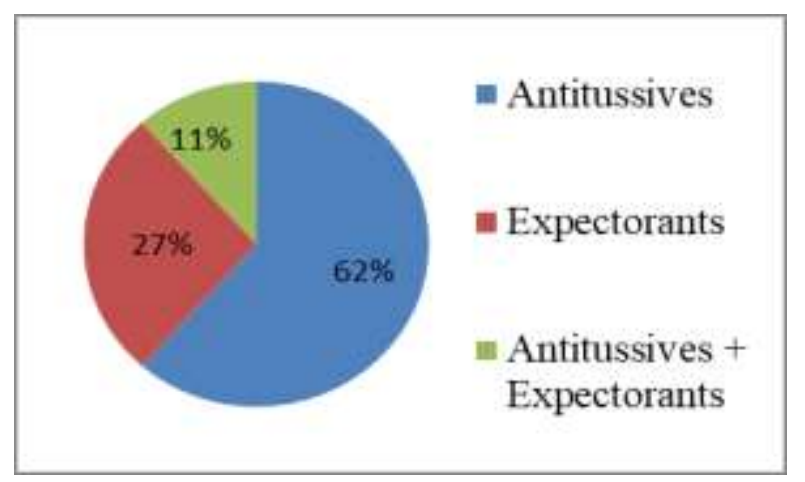

Figure 2: Percentage of antitussive expectorants and their combinations.

Table 1: List of individual constituents in antitussiveexpectorant preparations.

\begin{tabular}{|c|c|}
\hline Groups & Constituents \\
\hline Antitussives & Dextromethorphan, codeine \\
\hline Expectorants & Guaifenesin, ammonium chloride \\
\hline Mucolytics & Bromhexine, ambroxol \\
\hline Bronchodilators & $\begin{array}{l}\text { Salbutamol, levosalbutamol, } \\
\text { terbutaline }\end{array}$ \\
\hline Anti-histaminic & $\begin{array}{l}\text { Chlorpheniramine, } \\
\text { diphenhydramine }\end{array}$ \\
\hline $\begin{array}{l}\text { Nasal } \\
\text { decongestants }\end{array}$ & $\begin{array}{l}\text { Phenylephrine, } \\
\text { phenylpropanolamine, } \\
\text { pseudoephedrine }\end{array}$ \\
\hline Others & Paracetamol, menthol \\
\hline
\end{tabular}

Table 2: Cost ratio and percentage cost variation of antitussive-expectorants available in the Indian market.

\begin{tabular}{|c|c|c|c|c|c|c|}
\hline $\begin{array}{l}\text { Drugs/ fixed dose combinations/ } \\
\text { dosage formulations }\end{array}$ & Dose (mg) & PC & $\begin{array}{l}\text { Max. } \\
\text { price }\end{array}$ & $\begin{array}{l}\text { Min. } \\
\text { price }\end{array}$ & $\begin{array}{l}\text { Cost } \\
\text { ratio }\end{array}$ & $\begin{array}{l}\text { Price } \\
\text { variation }(\%)\end{array}$ \\
\hline $\begin{array}{l}\text { Chlorpheniramine }+ \text { dextromethorphan }+ \\
\text { phenylephrine }(10 \text { tab) }\end{array}$ & $(2+10+5)$ & 3 & 78.80 & 48.00 & 1.625 & 62.50 \\
\hline $\begin{array}{l}\text { Chlorpheniramine + dextromethorphan+ } \\
\text { phenylephrine }(100 \mathrm{ml} \text { syp) }\end{array}$ & $(2+10+5)$ & 19 & 85.00 & 16.03 & 5.30 & 430.25 \\
\hline $\begin{array}{l}\text { Chlorpheniramine + dextromethorphan + } \\
\text { phenylephrine ( } 60 \mathrm{ml} \text { syp) }\end{array}$ & $(2+10+5)$ & 5 & 55.00 & 27.00 & 2.03 & 103.70 \\
\hline $\begin{array}{l}\text { Phenylephrine + chlorpheniramine + } \\
\text { paracetamol (PCM) }(60 \mathrm{ml} \text { syp })\end{array}$ & $(5+2+250)$ & 13 & 60.00 & 27.00 & 2.22 & 122.22 \\
\hline
\end{tabular}




\begin{tabular}{|c|c|c|c|c|c|c|}
\hline $\begin{array}{l}\text { Drugs/ fixed dose combinations/ } \\
\text { dosage formulations }\end{array}$ & Dose (mg) & $\mathbf{P C}$ & $\begin{array}{l}\text { Max. } \\
\text { price }\end{array}$ & $\begin{array}{l}\text { Min. } \\
\text { price }\end{array}$ & $\begin{array}{l}\text { Cost } \\
\text { ratio }\end{array}$ & $\begin{array}{l}\text { Price } \\
\text { variation }(\%)\end{array}$ \\
\hline $\begin{array}{l}\text { Phenylephrine + chlorpheniramine + } \\
\text { PCM (10 tab) }\end{array}$ & $(5+2+500)$ & 5 & 40.00 & 24.00 & 1.66 & 66.66 \\
\hline $\begin{array}{l}\text { Terbutaline + guaifenesin }+ \text { ambroxol } \\
(100 \mathrm{ml} \text { syp })\end{array}$ & $(1.25+50+15)$ & 15 & 74.50 & 28.00 & 2.66 & 166.07 \\
\hline $\begin{array}{l}\text { Terbutaline + guaifenesin + bromohexine } \\
\text { (10 tab) }\end{array}$ & $(1.25+50+4)$ & 3 & 40.00 & 2.50 & 1.86 & 86.04 \\
\hline $\begin{array}{l}\text { Terbutaline + guaifenesin + bromohexine } \\
\text { (100 ml syp) }\end{array}$ & $(1.25+50+4)$ & 11 & 96.00 & 32.56 & 2.94 & 194.84 \\
\hline $\begin{array}{l}\text { Ambroxol + guaifenesin + salbutamol } \\
(100 \mathrm{ml} \text { syp) }\end{array}$ & $(15+50+1)$ & 7 & 58.00 & 17.33 & 3.346 & 234.67 \\
\hline $\begin{array}{l}\text { Ambroxol + guaifenesin + levosalbutamol } \\
(100 \mathrm{ml} \mathrm{syp})\end{array}$ & $(30+50+1)$ & 17 & 100 & 55.00 & 1.81 & 81.81 \\
\hline Codeine + chlorpheniramine (100 ml syp) & $(10+4)$ & 17 & 72.00 & 35.04 & 2.05 & 105.47 \\
\hline $\begin{array}{l}\text { Dextromethorphan + bromohexine + } \\
\text { ammonium CL+ menthol }(100 \mathrm{ml} \text { syp })\end{array}$ & $(5+4+50+2.5)$ & 13 & 76.00 & 30.00 & 2.53 & 153.33 \\
\hline $\begin{array}{l}\text { Dextromethorphan + chloepheniramine } \\
\text { (100 ml syp) }\end{array}$ & $(10+4)$ & 18 & 80.50 & 25.75 & 3.126 & 212.621 \\
\hline Dextromethorphan (10 tab) & $(10)$ & 3 & 57.00 & 29.00 & 1.96 & 96.55 \\
\hline Dextromethorphan (10 tab) & $(20)$ & 3 & 80.00 & 50.00 & 1.60 & 60.00 \\
\hline Dextromethorphan (100 ml syp) & $(20)$ & 5 & 57.00 & 23.65 & 2.41 & 141.01 \\
\hline $\begin{array}{l}\text { Dextromethorphan + guaifenesin + } \\
\text { phenylephrine + chlorpheniramine }(100 \\
\text { ml syp) }\end{array}$ & $(10+100+25+4)$ & 5 & 70.50 & 59.90 & 1.17 & 17.69 \\
\hline $\begin{array}{l}\text { Chlorpheniramine }+ \text { dextromethorphan }+ \\
\text { phenylpropanolamine }(100 \mathrm{ml} \text { syp) }\end{array}$ & $(4+10+25)$ & 6 & 45.00 & 25.00 & 1.80 & 80.00 \\
\hline $\begin{array}{l}\text { Chlorpheniramine + phenylephrine }(100 \\
\text { ml syp) }\end{array}$ & $(2+5)$ & 4 & 85.00 & 32.00 & 2.65 & 165.62 \\
\hline $\begin{array}{l}\text { Dextromethotphan }+ \text { pseudoephdrine }+ \\
\text { diphenhydramine }(60 \mathrm{ml} \text { syp })\end{array}$ & $(7.5+15+25)$ & 5 & 42.50 & 35.82 & 1.186 & 18.64 \\
\hline $\begin{array}{l}\text { Dextromethorphan + phenylephrine + } \\
\text { chlorpheniramine + PCM (100 ml syp) }\end{array}$ & $(10+5+2+250)$ & 6 & 93.03 & 48.80 & 1.90 & 90.63 \\
\hline $\begin{array}{l}\text { Dextromethorphan + phenylephrine } \\
\text { chlorpheniramine + PCM } 250 \mathrm{mg}(60 \mathrm{ml} \\
\text { syp) }\end{array}$ & $(10+5+2)$ & 7 & 42.00 & 32.00 & 1.31 & 31.25 \\
\hline $\begin{array}{l}\text { Ambroxol + terbutaline + guaifenesin + } \\
\text { menthol (100 ml syp) }\end{array}$ & $(15+1.25+15+2)$ & 26 & 81.80 & 31.50 & 2.59 & 159.68 \\
\hline $\begin{array}{l}\text { Terbutaline + bromohexine + guaifenesin } \\
\text { menthol (100 ml syp) }\end{array}$ & $(1.25+2+50+2.5)$ & 14 & 92.00 & 39.00 & 2.35 & 135.89 \\
\hline $\begin{array}{l}\text { Dextromethorphan + guaifenesin }+ \\
\text { chlorpheniramine + ammonium chloride } \\
(100 \mathrm{ml} \text { syp) }\end{array}$ & $(10+100+4+60)$ & 4 & 49.50 & 39.00 & 1.26 & 26.92 \\
\hline $\begin{array}{l}\text { Dextromethorphan }+ \text { guaifenesin }+ \\
\text { chlorpheniramine }+ \text { ammonium chloride } \\
(60 \mathrm{ml} \text { syp) }\end{array}$ & $(10+100+4+60)$ & 4 & 39.90 & 20.00 & 1.995 & 99.50 \\
\hline
\end{tabular}

\section{DISCUSSION}

The results of our study show that there is a number of formulations available in the Indian market to treat cold and cough. More than $88 \%$ are FDCs and the maximum of such FDCs are irrational. This is despite the well-known fact that there is not a single product that will prevent, cure, or even shorten the course of the common cold. ${ }^{19,20}$ Antitussive should be prescribed for patients having dry cough and expectorants having productive cough. There is no uniformity in a combination of the formulation. These are frequently sold as over the counter medication, so there is ample chance of irrational use as cough formulations. Dry cough patients may get expectorant and productive cough patients' antitussive and vice-versa. Moreover, there is an irrational combination of both antitussive and expectorant in the same formulations. A Cochrane review found codeine, antihistamines, and antihistamine decongestant combination to be no more effective than a placebo. $^{21}$ No studies of expectorants that met their inclusion criteria were found. The review concluded that the evidence for the effectiveness of over-the-counter 
cough medicines is weak. In another review, there was little valid evidence for the efficacy of antihistamines in the common cold. ${ }^{22}$ In addition, it was stated that antihistamines may be harmful. A recent review panel of the US FDA on cough and cold medications has concluded that there is no justification for having more than three pharmacological groups in one FDC. ${ }^{23}$ In our study, the number of pharmacological groups in the FDC's ranged from 1 to 5 . The number of constituents from the same pharmacological group was present with some preparations showing more than one expectorant in many FDC. The efficacy and rationality of more than one expectorant in one FDC cannot be justified, when the efficacy and safety of not even a single expectorant has been recommended. ${ }^{19}$ If it is desired to increase a particular action of a drug, it is better to increase its dose or add another drug belonging to a different class. Many FDCs had constituents with opposing actions i.e., antitussives and expectorants. A great variation in the amount of the same constituent present per dose in different drug products for cough and cold was observed. We calculated the percentage price variation in the amount per dose available, because of the absence of clear indications and dosage recommendations for use of these constituents in cough and cold, no specified dosages are available that could be kept as standard for comparison. There is no system of registration of medicine in the Indian market even when more than 100,000 formulations are present. Many companies sell one formulation of drugs under a different name, which leads to greater price variation and unnecessary imposed severe economic burden. People in developing countries like India pay more money on drugs and supplements from their own pockets. In India, more than $80 \%$ of health-related expenses are carried out by patients themselves, so the price of medicine is an important factor for a healthy world. Most of the poor people choose to buy medicine or food or another necessary item for their survival due to limited resources available and the high price of medicine. ${ }^{24}$ Common cold and cough is prevalent in any part of India due to weather variation, which needs continuous treatment. The price of drugs is regulated by the drug price control order 2013 (DPCO). ${ }^{25}$ Hence, there was a need to pay attention to controlling the price of various drug formulations available in the Indian market to decrease the cost of therapy and increase patient compliance. ${ }^{26}$ The aim of our study is to create awareness among the clinician, so that they should prescribe economical drugs available and ultimately patient and community will have to bear lesser money and decrease financial burden.

\section{Limitations}

Our study has a few limitations like we considered a limited number of brands of antitussive -expectorants drugs as mentioned in drug today even though there are many other brands available in the market. The prices of the generic medicines that have been obtained were not compared with other sources. Hence, similar studies should be done on a larger scale based on the same therapeutic class of drugs to overcome these limitations and give us a better picture of cost variation in the Indian pharmaceutical market.

\section{CONCLUSION}

Along with safety and efficacy, the cost of drugs is also considered in account for making any drug formulations and the national list of essential medicines (NLEM), because it plays a vital role in the health care system in developing countries like India. At present, the price of a few drugs is controlled by the government under the drug price control order (DPCO). The clinicians should always make a balance between patient clinical conditions and socio-economic status while prescribing a drug. It is time to think and create awareness about price variation of drugs among the public, consumers, health care payers, health care providers, government, policymakers and even pharmaceuticals for action taken to improve to cut down the economic burden on patients and also because of the health care system.

\section{ACKNOWLEDGEMENTS}

Author would like to thanks to Dr. Aakanksha Priya J. R. (Acad), department of pharmacology AIIMS Patna for immense help and cooperation.

Funding: No funding sources Conflict of interest: None declared

Ethical approval: The study was approved by the Institutional Ethics Committee of AIIMS Patna (Ref. No. AIIMS/Pat/IEC/2020/734 Dated 29/06/2021).

\section{REFERENCES}

1. World Health Organization. The rational use of drugs. Report of the conference of experts. Geneva: World Health Organization; 1985. Available at: http://www.apps.who.int/medicinedocs/en/m/abstract/ Js17054e/ Accessed on 13 November 2021.

2. Holloway K, Dijk VL. Rational Use of Medicines World Medicines Situation Report. World Health Organization; 2011. Report No. WHO/EMP/MIE/2011.2.2. Available at: http://www. who.int/medicines/areas/policy/world_medicines_situ ation/WMS_ch14_wRational Accessed on 13 November 2021.

3. World Health Organization- Country Office for India. Promoting Rational Drug Use under NRHM, 2009. Available http://hsrii.org/wpcontent/uploads/2014/05/Promoting _Rational_Drug_use_under_NRHM_NHSRC_WHO1 Accessed on 13 November 2021.

4. Tripathi KD. Essentials of Medical Pharmacology. Jaypee publishers New Delhi, $8^{\text {th }}$ Ed. 2018;227-8.

5. Gibson PG, Simpson JL, Ryan NM. Mechanisms of cough. Curr Opin Allergy Clin Immunol. 2014;14:5561. 
6. Munyard P, Bush A. How much coughing is normal? Arch Dis Child. 1996;74:531-4.

7. Chang AB, Glomb WB. Guidelines for evaluating chronic cough in pediatrics: ACCP evidence-based clinical practice guidelines. Chest. 2006;129:260S-83.

8. Galway NC, Shields MD. The child with an incessant dry cough. Paediatr Respir Rev. 2019;30:58-64.

9. Gilchrist FJ. An approach to the child with a wet cough. Paediatr Respir Rev. 2019;31:75-81.

10. Morice A, Kardos P. Comprehensive evidence-based review on European antitussives. BMJ Open Resp Res. 2016;3:e00137.

11. Cohen HA, Rozen J, Kristal H. Effect of honey on nocturnal cough and sleep quality: a double-blind, randomized, placebo-controlled study. Pediatrics. 2012;130:465-71.

12. Hay AD, Wilson A, Fahey T. The duration of acute cough in pre-school children presenting to primary care: a prospective cohort study. Fam Pract 2003;20:6.

13. Morice AH, McGarvey L, Pavord I. Recommendations for the management of cough in adults. Thorax. 2006;61(1):1-24.

14. Thompson M, Vodicka TA, Blair PS. Duration of symptoms of respiratory tract infections in children: systematic review. BMJ. 2013;347:f7027.

15. National Institute for Health and Care Excellence. Cough (acute): antimicrobial prescribing. NICE guideline. London: NICE National Institute for Health and Care Excellence. 2019.

16. Rimsza ME, Newberry S. Unexpected infant deaths associated with use of cough and cold medications. Pediatrics. 2008;122:e318-22.

17. Srivastava SK. Medical Pharmacology. Avichal publishing company, New Delhi, $2^{\text {nd }}$ Ed. 2017;438.

18. Eaddy MT, Cook CL, O’Day K, Burch SP, Cantrell CR. How patients cost-sharing trends affects adherence and out comes: a literature review. PT. 2012;37(1):45-55.

19. Hecht A. The common cold: relief but no cure. Available at: http//www.hoptechno.com/book64htm. Accessed on May 20, 2021.

20. Simasek M, Blandino DA. Treatment of the common cold. Am Fam Physician. 2007;75:515-20.

21. Schroeder K, Fahey T. Over the counter medication for acute cough in children and adult in ambulatory setting. Cochrane database Syst Rev. 2004;18:CD001831.

22. West S, Brandon B, Stolley P, Rumrill R. A review of antihistamines and the common cold Pediatrics. 1975;56:100-7.

23. Hussein SH. cough mixtures. 1996. Available at: http://www.prn2.usm.my/mainsite/bulletin/sun/1996/ sun39.html. Accessed on May 20, 2021.

24. Thomas M. Rational drug use and essential drug concept. In: Parthasarthi G, Nyfort Hasen K, eds. A textbook of clinical pharmacy practice. $1^{\text {st }}$ ed. Hyderabad: Orient Longman. 2004;723.

25. Drug Cost Control. Government of India, 2013. Available at: http://www.nppaindia.nic.in/ DPCO2013. Accessed on 13 November 2021.

26. Vieira JL, Portal VL, Moriguchi EH. How much do we pay for a benefit? The need for a national costeffectiveness analysis. Arq Bras Cardiol. 2001;76(5):409-18.

Cite this article as: Manjhi PK, Singh SK, Kumar $\mathrm{C}$, Rana AK. Rational use and cost variation analysis of antitussive-expectorants available in the Indian market: a pharmacoeconomic study. Int J Basic Clin Pharmacol 2021;10:1342-7. 